\title{
TaqMan Real-Time Quantification of Epstein-Barr Virus in Severe Early Childhood Caries
}

Sibel Yildirima

Esma Yildiz ${ }^{a}$

Ayhan Kubarb

\section{ABSTRACT}

Objectives: Early childhood caries (ECC) has several risk factors and it is important stressful/ painful events of childhood and immunosuppression may occur during this unique rampant caries pattern. The changes in the host immune competence by compromised cellular immune system functions can activate Epstein Barr virus (EBV). The objective of this study was to determine whether the supragingival plaque samples of severe-ECC (S-ECC) patients harbor more EBV load than the non-carious healthy children by quantitative TaqMan Real-Time polymerase chain reaction (PCR).

Methods: Sixty subjects, including 30 S-ECC patients as well as age and gender matched 30 caries-free patients were studied. The supragingival plaque samples were collected from patients by brushing their teeth for 1 minute and the toothbrush was washed in $1 \mathrm{ml}$ of sterile deionized water. After viral DNA extraction, TaqMan real-time PCR assay was used to quantify EBV DNA. Dental treatments were completed for all S-ECC patients and they were called for routine controls. Only 10 treated S-ECC patients were come to the $3^{\text {rd }}$ months' control and post-treatment viral sampling was made in the same manner.

Results: EBV DNA was detected 16 of 30 S-ECC patients and 6 of the healthy controls $(P<.001)$. There was no relationship between baseline and post-treatment samples of 10 treated S-ECC patients.

Conclusions: The results of the study suggest that oro-dental hygiene motives of S-ECC patients might be important contributory factor for S-ECC and EBV would not be involved in the etiopathogenesis of ECC. (Eur J Dent 2010;4:28-33)

Key words: Early childhood caries, Epstein-Barr virus; TaqMan Real-Time PCR.

I- a Selcuk University, Faculty of Dentistry, Department of Pediatric Dentistry, Konya, Turkey.

b Gulhane Military Medical Academy, Department of Virology, Etlik, Ankara, Turkey.

Corresponding author: Esma Yildiz Selcuk University, Faculty of Dentistry, Department of Pediatric Dentistry, Kampus, 42031 Konya,Turkey.

Phone: +90332 2231144

Fax: +903322410062

E-mail: esma_yildizahotmail.com

\section{INTRODUCTION}

The expression early childhood caries is currently used to replace the terms baby-bottle tooth decay and nursing caries. ECC is defined as the presence of one or more decayed (noncavitated or cavitated lesions), missing (due to caries), or filled tooth surfaces' in any primary tooth in a child 71 mounts of age and younger. In children younger than 3 years of age, any sign of smooth-surface 
caries is indicative of severe early childhood caries (S-ECC). From ages 3 through 5, 1 or more cavitated, missing (due to caries), or filled smooth surfaces in primary maxillary anterior teeth or a decayed, missing, or filled score of $\geq 4$ (age 3), $\geq 5$ (age 4), or $\geq 6$ (age 5) surfaces constitutes S-ECC. ${ }^{1-3}$ ECC is to be accepted as an infectious disease and $S$. mutans is the most likely infectious agent. Diet also plays a crucial role in the clinical expression of this infection. 2,4

The unique distribution of caries pattern, unequal severity of lesions between the incisors and the other teeth and the early beginning in loss of tooth substance may indicate the different microbial flora of ECC than the other forms of enamel caries. However the results from the previous studies indicate that there is non-specific etiology for S-ECC. ${ }^{5}$

EBV infection is usually transmitted between individuals in saliva, and establishes replicative infection within the oropharynx as well as life-long latent infection of $B$ cells. During the subsequent lifelong infection, the virus carriers do not manifest symptoms as long as they are immunocompotent. EBV has evolved a successful strategy of immune evasion without disturbing the immune homeostasis of the host ${ }^{6}$ and periodic reactivation of EBV results in the shedding of virions into saliva. $^{7}$

Having the fact that an activation of herpesviruses (latent or acute) in oral tissues may occur spontaneously or as a result of the problems encountered for impairing the host immune defense we would like to search if immunsuppression is a contributory factor for S-ECC. The objective of this study was to determine whether the supragingival plaque samples of S-ECC patients harbor more EBV load than the non-carious healthy children by quantitative TaqMan Real-Time polymerase chain reaction (PCR).

\section{MATERIALS AND METHODS}

The 30 S-ECC patients were selected from a group of children attending the Pediatric Dentistry clinics of Selcuk University Faculty of Dentistry, Konya, Turkey. The 30 caries-free age and gender matched patients as control group were selected from the same attendant of patients. $\mathrm{Pa-}$ rental informed consent was obtained for all patients before they were examined. All procedures were approved by the ethical committee of Selcuk University Faculty of Dentistry and the parents provided written informed consent after the procedure were fully explained.

S-ECC was defined in children with at least four incisors presenting carious lesions beyond the white spot stage. Caries prevalence was evaluated using the dmft $(d=$ decayed, $m=$ missing, $f=$ filled, $\mathrm{t}=$ teeth) indexes.

Dental treatment for the patients was completed and detailed instructions regarding oral hygiene were given to the parents and children. The parents informed about regular follow-up visits in every three months until the oral hygiene status of the children find satisfactory by their dentist. Unfortunately only 10 of the 30 treated S-ECC patients were responded to their 3 months controls.

Supragingival plaque collection

A sterile toothbrush was used to collect dental plaque from teeth as previously described by Okada et al. ${ }^{8}$ In brief, the children brushed their teeth for 1 min under the supervision of a dental professional. The toothbrush was washed vigorously in a plastic vial containing $1 \mathrm{ml}$ sterile deionized water. The post-treatment supragingival plaque samples of dentally treated-ten patients were also collected in the same manner.

\section{Viral assessment}

A 5'-nuclease (TaqMan) real-time PCR assay was used to identify and quantify genomic copies of EBV. DNA was extracted using an alkali phenolchloroform-isoamyl alcohol (25: 24:1) procedure. Extracted DNA was re-suspended in $100 \mu \mathrm{l}$ of distilled water, and $5 \mu \mathrm{l}$ of the DNA solution was used in the real-time PCR assay. PCR primers, TaqMan probes and TaqMan real-time assay conditions are described elsewhere. ${ }^{9}$ Quantification of viral load was previously explained in detail. ${ }^{10}$ In brief, the EBV genomes were amplified and the amplicons cloned with TOPO-TA Cloning Kit (Invitrogen, Carlsbad, CA, USA). The plasmid was used for EBV quantification. Serial dilutions of plasmid DNA $\left(10^{1}-10^{8}\right.$ plasmids $\left./ \mathrm{ml}\right)$ were used to determine the dynamic range of quantification. Plasmid standards were calculated using Oligoware 2.0, ${ }^{9}$ and TaqMan Real-Time PCR assay was performed in a Perkin-Elmer 7700 Sequence Detection System (Applied Biosystems, Foster City, CA, USA). The 
amplification mix contained 1X Taq-Man Buffer A $1500 \mathrm{mM} \mathrm{KCl}, 100$ mM Tris-HCl, 100 mM EDTA, $600 \mathrm{nM}$ passive reference $\mathrm{A}, \mathrm{pH} 8.3$ at room temperature), 4 pmol of probe, 5 pmol of each primer, $0.2 \mathrm{mM}$ of each dNTP, $6 \mathrm{mM} \mathrm{MgCl}, 1.0 \mathrm{U}$ hot start Taq polymerase (AmpliTaq Gold DNA Polymerase, Applied Biosystems) and $5 \mu$ template in total volume of $25 \mu \mathrm{l}$. The reaction conditions for all templates were $2 \mathrm{~min}$ at $50^{\circ} \mathrm{C}, 10 \mathrm{~min}$ at $95^{\circ} \mathrm{C}$, and 40 cycles with $15 \mathrm{~s}$ at $95^{\circ} \mathrm{C}$ and $1 \mathrm{~min}$ at $60^{\circ} \mathrm{C}$. All PCR assays were performed in triplicate.

ECC and control groups were compared via ttest, ANOVA and Tukey Post Hoc Test in terms of age, sex and viral load. Baseline and post-treatment samples of 10 patients were compared by t-test.

\section{RESULTS}

The study population was composed of 60 subjects 130 S-ECC patient and 30 control subjects) with a mean age of $4.36 \pm 0.08$ years. There was no difference between the S-ECC and cariesfree control groups with respect to age or gender (Table 1). The mean value for dmft score in S-ECC patients was $8.36 \pm 3.17$.

Table 2 shows positive samples to the range between $10^{2}$ and $10^{7}$ of the supragingival plaque samples of S-ECC and control patients. The viral load values obtained from TaqMan Real-Time PCR were normalized by taking normal logarithm of viral load values in base 10 . Meanwhile, t-test showed that there was statistically significant relation between the test and control groups $(t=2.75$, $d f=5.8, P=0.008)$. The mean value and standard deviation (SD) of viral load of test group and control group were $1.0 \pm 2.2$ and $2.6 \pm 2.4$, respectively. ANOVA showed that viral load and age displayed statistically significant relation $(F=3.19, d f=4$, $\mathrm{P}=0.02)$. Then multiple comparisons of Tukey Post Hoc Test showed that age and viral load displayed significant difference between 3 and 6 years of age (for 3 and 6 years of age mean $\pm S D$ were $0.34 \pm 1.03$; and $3.38 \pm 2.77$, respectivelyl. On the hand the viral load and sex displayed no relationship statistically.

There was no statistically significant relationship between the ten treated patients' baseline and post-treatment samples (Table 3$)(t=-1,611$; $d f=18 ; P=0.125)$.

\section{DISCUSSION}

There is no relevant study searching the possible relationships between immunosuppression and ECC. Since EBV is more prevalent among immunocompromised patients and it has been shown as important etiopathogenetic factor for aggressive periodontal disease, ${ }^{11}$ we quantified EBV DNA in supragingival samples of S-ECC patients via TaqMan real-time PCR. We showed statistically significant difference for EBV load between S-ECC and caries-free control group. S-ECC is a painful and stressful event for children and toddlers and this situation might activate EBV as a result of changes in the host immune competence. ${ }^{12}$

However, the results obtained from 10 treated S-ECC patients' supragingival samples, which were collected in their $3^{\text {rd }}$ month's controls, showed no viral load reducing after the treatment. We believe that those results rose from the fact that, S-ECC patients have poor oral hygiene habits. Since, ECC has significant risk factors such as, poor oral hygiene, inadequate home dental care, a mother with a number of cavities, a high sugar intake, enamel defects, special health care needs, low socioeconomic status etc., re-gaining well-being situation for those patients would be difficult. ${ }^{13}$ Accordingly, the high EBV occurrence in S-ECC group would reflect those obstacles which directly related with oral health. In this view, making restorative and preventive therapies including use of fluorides, sealants; promoting early oral hygiene instruction and counseling parents to make necessary changes in their child's dietary habits are very important for obtaining satisfactory oral hygiene for ECC patients.

A possible explanation for the association between EBV and dental caries is a challenging issue, although we do not think that EBV involves directly in the etiopathogenesis of S-ECC. However, there might be a possibility for establishing a link between the specific measurable changes in the immune system in stress situation and ECC. Since painful lesions of ECC is an important stress factor for child and toddlers, antibody-mediated defense mechanisms of oral infections might be impaired in ECC patients compared to that of healthy subjects. Most bacterial oral infections are handled by secretory immunity lincluding Secretory $\lg A)$ or the antibody (IgG)-complement neutrophil axis. This secretory immune system is of paramount importance. When EBV reactivated as a result of changes in the host immune competence, ${ }^{12}$ antibodies to EBV which are mostly IgA 
Table 1. Mean age (in years) of the subjects in the study, and their distribution according to group and sex.

\begin{tabular}{|c|c|c|c|c|}
\hline & Age & Sex & & \\
\hline Group & Mean $\pm S D$ & $M(\%)$ & $F(\%)$ & $\mathrm{n}$ \\
\hline S-ECC* & $4.7 \pm 1.1$ & $21(70 \%)$ & $9(30 \%)$ & 30 \\
\hline Control & $4.7 \pm 1.2$ & $16(53.3 \%)$ & $14(46.7 \%)$ & 30 \\
\hline
\end{tabular}

*S-ECC: Severe-early childhood caries

Table 2. The results of Epstein-Barr virus (EBV) DNA quantification via Taq-Man Real-Time PCR Assay for supragingival plaque samples from severe-early childhood caries (S-ECC) and control group.

\begin{tabular}{|c|c|c|c|c|c|c|c|}
\hline \multicolumn{5}{|c|}{ S-ECC Group } & \multicolumn{3}{|c|}{ Control Group } \\
\hline Subject no. & Gender & Age & EBV viral load $/ \mathrm{ml}$ & Subject no. & Gender & Age & EBV viral load $/ \mathrm{ml}$ \\
\hline 1. & $\mathrm{~F}$ & 5 & $3,4 \times 10^{3}$ & 1. & M & 3 & 0 \\
\hline 2. & $\mathrm{~F}$ & 3 & $1,2 \times 10^{2}$ & 2. & $\mathrm{~F}$ & 6 & $3,3 \times 10^{2}$ \\
\hline 3. & M & 4 & $2,1 \times 10^{5}$ & 3. & $\mathrm{~F}$ & 4 & 0 \\
\hline 4. & $\mathrm{~F}$ & 3 & 0 & 4. & $\mathrm{~F}$ & 4 & 0 \\
\hline 5. & M & 3 & 0 & 5. & M & 3 & 0 \\
\hline 6. & $\mathrm{~F}$ & 4 & $5,1 \times 10^{3}$ & 6. & M & 6 & 0 \\
\hline 7. & M & 3 & 0 & 7. & M & 4 & 0 \\
\hline 8. & M & 6 & & 8. & M & 6 & 0 \\
\hline 9. & $\mathrm{~F}$ & 5 & $1,7 \times 10^{6}$ & 9. & $\mathrm{~F}$ & 5 & 0 \\
\hline 10. & M & 6 & $4,6 \times 10^{5}$ & 10. & M & 6 & $1,2 \times 10^{6}$ \\
\hline 11. & M & 6 & $3,7 \times 10^{3}$ & 11. & $\mathrm{~F}$ & 4 & 0 \\
\hline 12. & M & 5 & $1,5 \times 10^{5}$ & 12. & $\mathrm{~F}$ & 5 & 0 \\
\hline 13. & M & 6 & $5,7 \times 10^{7}$ & 13. & $\mathrm{~F}$ & 5 & 0 \\
\hline 14. & M & 5 & $5,0 \times 10^{6}$ & 14. & $\mathrm{~F}$ & 7 & 0 \\
\hline 15. & M & 4 & 0 & 15. & M & 6 & 0 \\
\hline 16. & M & 6 & $1,7 \times 10^{5}$ & 16. & M & 4 & 0 \\
\hline 17. & M & 4 & 0 & 17. & $\mathrm{~F}$ & 6 & $4,6 \times 10^{3}$ \\
\hline 18. & $\mathrm{~F}$ & 7 & 0 & 18. & M & 3 & 0 \\
\hline 19. & M & 4 & $5,0 \times 10^{3}$ & 19. & M & 4 & 0 \\
\hline 20. & M & 6 & 0 & 20. & $\mathrm{~F}$ & 3 & 0 \\
\hline 21. & $\mathrm{~F}$ & 5 & 0 & 21. & $\mathrm{~F}$ & 5 & 0 \\
\hline 22. & M & 6 & $9,1 \times 10^{2}$ & 22. & F & 5 & 0 \\
\hline 23. & M & 4 & 0 & 23. & $\mathrm{~F}$ & 4 & 0 \\
\hline 24. & M & 4 & $3,6 \times 10^{3}$ & 24. & $\mathrm{~F}$ & 4 & 0 \\
\hline 25. & M & 6 & 0 & 25. & M & 6 & $3,6 \times 10^{6}$ \\
\hline 26. & M & 4 & 0 & 26. & M & 6 & $6,2 \times 10^{5}$ \\
\hline 27. & $\mathrm{~F}$ & 5 & 0 & 27. & M & 3 & 0 \\
\hline 28. & M & 4 & $3,6 \times 10^{4}$ & 28. & M & 6 & $4,6 \times 10^{5}$ \\
\hline 29. & $\mathrm{~F}$ & 4 & $8,5 \times 10^{3}$ & 29. & M & 4 & 0 \\
\hline 30. & M & 4 & $2,1 \times 10^{2}$ & 30. & M & 4 & 0 \\
\hline
\end{tabular}


might not be produced. Secretory IgA has crucial roles to bathe tooth surfaces and to inhibit colonization by $S$. mutans. ${ }^{14}$ Since EBV periodontal presence is associated with an elevated occurrence of periodontopathic anaerobic bacteria ${ }^{11}$ the balance between $\lg \mathrm{A}$ and EBV level in saliva might have some importance in etiopathogenesis of severe caries patterns.

The arguments we tried to explain above do not rule out that S-ECC patients would be strong candidates for periodontal disease in their future life. Since we showed an ineffectiveness of dental treatment on viral load for S-ECC patients in this study, EBV might survive in the oral environment (supragingival plaque and the most possibly in salival and would be related to future periodontal illness. Saygun et al ${ }^{15}$ have showed that periodontitis lesions are a source of salivary cytomegalovirus and EBV. Thus measurements for EBV load and/or IgA level in saliva or supragingival plaque may provide a valuable tool for monitor ECC disease prognosis and thereby reduce or prevent EBV transmission and EBV-related oral and non-oral diseases among close acquaintances may have significant public health implications. ${ }^{11}$

\section{CONCLUSIONS}

Future studies should include the search for salivary EBV DNA and infectious EBV in parallel to the detection of EBV antibodies. In the next step of this study it needs to be determined if S-ECC

Table 3. Baseline and post-treatment viral load results for 10 patients of S-ECC.caries (S-ECC) and control group.

\begin{tabular}{lc|cc}
\hline Gender & Age & $\begin{array}{r}\text { Baseline EBV } \\
\text { viral load/ml }\end{array}$ & $\begin{array}{c}\text { Post-treatment EBV } \\
\text { viral load/ml }\end{array}$ \\
\hline M & 6 & 0 & $9,1 \times 10^{2}$ \\
M & 4 & $2,1 \times 10^{5}$ & $4,3 \times 10^{3}$ \\
M & 6 & 0 & 0 \\
F & 4 & 0 & $2,6 \times 10^{6}$ \\
F & 4 & 0 & 0 \\
M & 4 & 0 & $8.6 \times 10^{5}$ \\
F & 5 & 0 & 0 \\
\hline F & 5 & 0 & $7,6 \times 10^{8}$ \\
M & 6 & $4.6 \times 10^{5}$ & $6,1 \times 10^{9}$ \\
M & 5 & $5.0 \times 10^{6}$ & $5.0 \times 10^{9}$ \\
\hline
\end{tabular}

patients with high post-treatment EBV loads will be at greater risk for further periodontal disease than caries-free children.

\section{ACKNOWLEDGEMENTS}

The authors wish to thank Yakup Alptekin; Hülya Aydın and Nazif Esin for their excellent technical assistance and to Assoc. Prof. Abdullah Kocak for his helps and comments for statistical evaluations.

\section{REFERENCES}

1. American Academy of Pediatric Dentistry (AAPD). Reference Manual 2003-2004. Pediatr Dent 2003;25:54.

2. Berkowitz RJ. Cause, treatment and prevention of early childhood caries. J Can Dent Assoc 2003;69:304-307.

3. Ismail Al, Sohn W. A systematic review of clinical diagnostic criteria of early childhood caries. J Public Health Dent 1999;59:171-191.

4. Harris R, Nicoll AD, Adair PM, Pine CM. Risk factors for dental caries in young children: a systematic review of the literature. Community Dent Health 2004;21(Supply);71-85.

5. Marchant S, Brailsford SR, Twomey AC, Roberts GJ, Beighton $D$. The predominant microflora of nursing caries lesions. Caries Res 2001;35:397-406.

6. Ohga S, Akihiko N, Hidetoshi T, Hara T. Immunological aspects of Epstein-Barr virus infection. Crit Rev Oncol Hematol 2002;44:203-215.

7. Balfour HH Jr, Holman CJ, Hokanson KM, Lelonek MM, Giesbrecht JE, White DR, Schmeling DO, Webb CH, Cavert W, Wang DH, Brundage RC. A prospective clinical study of Epstein-Barr virus and host interactions during acute infectious mononucleosis. J Infect Dis 2005;192:1505-1512.

8. Okada M, Hayashi F, Nagasaka N. Detection of Actinobacillus actinomycemcomitans and Porhyromonas gingivalis in dental plaque samples from children 2 to 12 years of age. $J$ Clin Periodontol 2000;27:763-768.

9. Yildirim S, Yapar M, Kubar A. Detection and Quantification of Herpesviruses in Kostmann Syndrome Periodontitis by Real-Time PCR. Oral Microbiol Immunol 2005;20:1-6.

10. Kubar A, Yapar M, Besirbellioglu B, Avci IY, Guney C. Rapid and quantitative detection of mumps virus RNA by one-step real-time RT-PCR. Diagn Microbiol Infect Dis 2004;49:8388.

11. Slots J, Saygun I, Sabeti M, Kubar A. Epstein-Barr virus in oral diseases. J Periodontal Res 2006;41:235-244.

12. Flint SJ, Enquist LW, Krug RM, Racainello VR, Skalka AM. Principles of virology, molecular biology, pathogenesis, and control. Washington D.C.: ASM press, 2002;543-546. 
13. Uribe S. Early childhood caries-risk factors. Evid Based Dent 2009;10:37-38.

14. Russell MW, Childers NK, Michale SM, Smith DJ, Taubman MA. A caries vacine? The state of the science of immunization against dental caries. Caries Res 2004;38:230-235.

15. Saygun I, Kubar A, Ozdemir A, Slots J. Periodontitis lesions are a source of salivary cytomegalovirus and Epstein-Barr virus. J Periodontal Res 2005;40:187-191. 